\title{
GAMBARAN PERILAKU PENCEGAHAN INFEKSI MENULAR SEKSUAL (IMS) DI TEMPAT HIBURAN KAWASAN WISATA SENGGIGI
}

\author{
*Siti Mardiyah WD, Catur Esty Pamungkas, Cahaya Indah Lestari \\ Fakultas IImu Kesehatan, Universitas Muhammadiyah Mataram, ${ }^{*}$ sitiwiredarma@gmail.com
}

\begin{abstract}
INFO ARTIKEL
Riwayat Artikel:

Diterima: $23-08-2019$

Disetujui: 23-01-2020

\section{Kata Kunci:}

Perilaku pencegahan Infeksi Menular Seksual HIV

AIDS

Senggigi

\section{ABSTRAK}

Abstrak: Provinsi Nusa Tenggara Barat (NTB) adalah salah satu destinasi wisata yang banyak diminati oleh turis domestik maupun mancanegara. Pantai Senggigi adalah salahsatunya. Sebagai daerah tujuan wisata, bukan hanya efek positif yang akan timbul, tetapi juga dampak negatifnya. Salah satu dampak negatif yang mungkin terjadi adalah penyebaran penyakit Infeksi Menular Seksual (IMS). Tujuan penelitian adalah mengetahui secara mendalam Gambaran Perilaku Pencegahan IMS di Tempat Hiburan Kawasan Wisata Senggigi. Penelitian ini menggunakan metode kualitatif. Subyek penelitian adalah pemilik Cafe, Club dan Spa. Triangulasi penelitian adalah KPA. Subyek penelitian diambil secara purposive. Tekhnik pengumpulan data menggunakan wawancara mendalam. Hasil penelitian menunjukkan Pemilik Tempat Hiburan melakukan pencehan IMS melalui keikutsertaan pada program KPA dan karena adangan dukungan Pemda dalam program penanggulangan HIV/AIDS melalui diterbitkannya Perda tentang pelaksanaan pemberian kartu kunjungan kesehatan. KPA sebagai pemegang kendali dalam pelaksanaan program dengan bekerjasama lintas sektor. Disarankan perlu partisipasi aktif dari stakeholders dalam kebijakan untuk meningkatkan perhatian terhadap pekerja di tempat hiburan yang terinfeksi IMS dan menjadikan isu HIV/AIDS sebagai kasus yang harus segera ditangani dan menjadi salah satu target pembangunan daerah sesuai dengan target SDG's.
\end{abstract}

\begin{abstract}
West Nusa Tenggara Province (NTB) is one of the tourist destinations that are in high demand by domestic and foreign tourists. Senggigi Beach is one of them. As a tourist destination, not only the positive effects will arise, but also the negative impacts. One negative impact that may occur is the spread of sexually transmitted infections (STIs). The purpose of this research is to find out in-depth the Image of Preventive Behavior of STIs in the Senggigi Tourism Area Entertainment Venues. This study uses a qualitative method. The research subjects are Cafe, Club and Spa owners. The research triangulation is KPA. The research subjects were taken purposely - data collection techniques using in-depth interviews. The results of the study show that the owner of the Entertainment Place conducts an STI chatter through participation in the KPA program and because of the support of the Regional Government in the HIV / AIDS prevention program through the issuance of a Regional Regulation on the implementation of the provision of health visit cards. KPA as the holder of control in the implementation of the program in collaboration across sectors. It is recommended that active participation of stakeholders in the policy is needed to increase the attention of workers in entertainment venues infected with STIs and make the issue of HIV / AIDS a case that must be immediately addressed and become one of the regional development targets in accordance with the SDG's target.
\end{abstract}

\section{A. LATAR BELAKANG}

Penyakit Menular Seksual (PMS) merupakan salah satu Infeksi Saluran Reproduksi (ISR) yang ditularkan melalui hubungan kelamin. Infeksi saluran reproduksi merupakan infeksi yang disebabkan oleh masuk dan berkembangbiaknya kuman penyebab infeksi ke dalam saluran reproduksi. Kuman penyebab infeksi tersebut dapat berupa jamur, virus, dan parasit. Salah satu penyakit menular seksual yaitu Human Immunodeficiency Virus (HIV)/ Acquired Immune Deficiency Syndrome (AIDS) (Ardhiyanti, 2015).
HIV/AIDS merupakan penyebab kedua utama kematian yang terdapat di dunia (Paul A. Bourne, 2010). Jumlah kumulatif kasus terbanyak pada Afrika Selatan dan Afrika Timur sekitar 19,4 juta orang, sementara di Asia dan Pasifik sekitar 5,1 juta orang. Secara global, jumlah orang yang hidup dengan HIV/AIDS sekitar 36,7 juta orang hingga tahun 2016 dan sekitar 1,8 juta orang yang baru terinfeksi HIV (UNAIDS, 2017).

Provinsi Nusa Tenggara Barat (NTB) adalah salah satu destinasi wisata yang banyak diminati oleh turis domestik maupun mancanegara. Sebagai daerah tujuan wisata, bukan hanya efek positif yang akan timbul, tetapi juga dampak negatifnya. Salah satu dampak negatif yang 
mungkin terjadi adalah penyebaran penyakit Infeksi Menular Seksual (IMS) lainnya, antara lain penyakit syphilis dan HIV/AIDS. Berdasarkan laporan, pada tahun 2015 jumlah kasus IMS (syphilis) sebanyak 63 orang mengalami penurunan di tahun 2016 menjadi 55 orang dan banyak terjadi pada kelompok umur 25-49 tahun. Berdasarkan laporan Voluntary Counseling And Testing (VCT). Pada tahun 2017 jumlah kasus HIV/AIDS yang ditemukan mengalami peningkatan dibandingkan tahun 2016. Jumlah kasus yang ditemukan tahun 2016 adalah 62 kasus HIV dan 87 kasus AIDS, sedangkan tahun 2017 ditemukan 98 kasus HIV, dan 111 kasus AIDS. Jumlah kematian karena AIDS di Provinsi NTB tahun 2016 sebanyak 9 kasus, mengalami peningkatan menjadi 22 kasus tahun 2017. Kota/Kabupaten yang terinfeksi HIV/AIDS paling tinggi yaitu Kota Mataram (39 kasus) diikuti Kabupaten Lombok Barat (34 kasus), Kabupaten Lombok Tengah (21 kasus ), Kabupaten Lombok Timur (20 kasus), Kabupaten Sumbawa Besar (17 kasus), Kabupaten Bima (6 kasus), Kota Bima (5 kasus), Kabupaten Lombok Utara (4 kasus) dan Kabupaten Sumbawa Barat (1 kasus) (Dinkes NTB, 2017).

Kegiatan program PMS/IMS dan HIV/AIDS dilaksanakan melalui pemeriksaan dan pengobatan di 5 Puskesmas yaitu Puskesmas Ampenan, Puskesmas Dasan Agung, Puskesmas Pagesangan, Puskesmas Cakranegara dan Puskesmas Karang Taliwang melalui Layanan Komperehensif HIV/IMS Berkesinambungan (LKB), klinik Voluntary Counseling And Testing (VCT) Rumah Sakit Umum Mataram, Klinik VCT Rumah Sakit Jiwa Mataram serta Klinik Infeksi Menular Seksual (IMS) Perkumpulan Keluarga Berencana Indonesia (PKBI) Mataram. Kunjungan di unit layanan IMS pada tahun 2015 sebanyak 3814 orang lebih sedikit dibandingkan kunjungan pada tahun 2014 yaitu 4270 orang, namun kunjungan per bulannya sangat berfluktuatif. Pada tahun 2015 jumlah penderita HIV/AIDS yang di temukan di kota mataram sejumlah 47 orang. Berdasarkan kelompok umur jumlah kasus HIV/AIDS tertinggi yaitu kasus HIV antara 20 - 29 tahun (40,91 \%) dan AIDS antara umur 30 - 39 tahun (31,82 \%). (Dinkes Kota Mataram, 2015).

Data kumulatif kasus HIV AIDS Kabupaten Kota di Provinsi NTB dari Tahun 1992 sampai Bulan Mei 2018, Kabupaten Lombok Barat berada pada urutan ke -3 di bawah Kota Mataram dan Lombok Timur. Jumlah penderita di Lombok Barat untuk HIV adalah sebanyak 126 orang dan penderita AIDS sebanyak 114 orang (KPA Lombok Barat, 2018).

Kabupaten Lombok Barat memiliki perairan pantai yang merupakan destinasi wisata yang selalu ramai dikunjungi salah satunya adalah Pantai Senggigi. Senggigi selain memiliki panorama pantai yang menarik para wisatawan, juga terdapat banyak hotel dan tempat hiburan seperti kafe, spa dan lainnya. Hal ini sangat memungkinkan terjadinya transaksi seksual bagi para pendatang dan hal ini dapat menjadi salah satu faktor meningkatnya prostitusi di pulau Lombok yang dapat meningkatkan penularan penyakit IMS dan HIV/AIDS.

\section{B. METODE PENELITIAN}

Penelitian ini menggunakan metode kualitatif. Subyek penelitian adalah pemilik Cafe, Club dan Spa. Triangulasi penelitian adalah KPA. Subyek penelitian diambil secara purposive. Tekhnik pengumpulan data menggunakan wawancara mendalam.

\section{HASIL DAN PEMBAHASAN}

Epidemi HIV/AIDS sudah menjadi masalah global, pemerintah Indonesia berkomitmen menjalankan kesepakatan internasional untuk pengendalian AIDS, mempromosikan kerjasama bilateral dan multilateral, serta memperluas kerjasama dengan negara tetangga dalam Program Pengendalian AIDS (Kemenkes RI, 2010).

World Health Organization (WHO) pada tahun 2005 memperkirakan bahwa setiap tahunnya pada kelompok umur 15-49 tahun terdapat lebih dari 448 juta kasus baru IMS yang dapat disembuhkan seperti gonore, klamidiasis, sifilis, dan trikomoniasis (Sridana \& Indrayani, 2012).

Hasil wawancara di dapatkan bahwa:

1. Pencegahan IMS

Perencanaan yang baik dan matang akan mempermudah pelaksanaan kegiatan sehingga tujuan suatu organisasi dapat tercapai sesuai harapan. Intervensi program kesehatan tidak mungkin bisa dilaksanakan tanpa adanya sember daya manusia yang memadai. Pengembangan SDM yang kompeten dan bermotivasi sangat penting dalam pencapaian tujuan program kesehatan.

\section{Kotak 1 \\ Apa saja program pencegahan IMS yang dilakukan?}

"Sesuai dengan aturan daerah sebelum penerimaan pegawai, mereka yang melamar harus melampirkan surat keterangaan sehat dari Puskesmas dan setiap 1 bulan dan 3 bulan sekali kami mengadakan tes kesehatan dari KPA dan Puskesmas" (KW 1)

"Petugas dari puskesmas rutin datang setiap 1 bulan dan 3 bulan, kemarin bulan April juga ada kegiatan pemeriksaan itu (IVA) dilakukan oleh Puskesmas"

"Kami diperiksa, diambil darahnya oleh petugas dari Puskesmas Gunung Sari dan petugas lain dari komisi HIV" (KW3)

Upaya pencegahan IMS dilakukan oleh KPA dan bekerjasama dengan Puskesmas dan LSM peduli HIV/AIDS di NTB khususnya di Lombok Barat. Upaya penanggulangan IMS di tempat wisata Senggigi telah tertuang dalam Perda 
Lombok Barat Nomor 3 tahun 2016 dan pasal 41 ayat 3 peraturan Bupati Lombok Barat Nomor 47 tahun 2014 tentang pencegahan dan penanggulangan HIV/AIDS termasuk IMS.

Kotak 2 Selain pemeriksaan kesehatan apakah ada
program lain untuk mencegah IMS?

"setelah pemeriksaan kesehatan dilakukan penyuluhan oleh komisi HIV itu" (KW1)

"kita diberikan penyuluhan juga kalau waktunya pemeriksaan kesehatan" (KW2)

"petugas dari KPA itu juga kasih penyuluhan disini, biasanya sebelum diperiksa kami diberikan informasi dulu, katanya konsultasi dulu"

Dukungan sosial merupakan salah satu strategi global menurut WHO dalam rangka promosi kesehatan. Kegiatan ditunjukkan kepada para tokoh masyarakat, baik formal (guru, lurah, camat, petugas kesehatan dan sebagainya) maupun informal (tokoh agama, dan sebagainya) yang mempunyai pengaruh di masyarakat. Tujuan kegiatan ini adalah agar kegiatan atau program kesehatan tersebut memperoleh dukungan dari tokoh masyarakat (toma) dan tokoh agama (toga). Selanjutnya toma dan toga diharapkan dapat menjembatani antara pengelola program kesehatan dengan masyarakat.

\section{Kotak 3 \\ Strategi apa yang dilakukan untuk meningkatkan terlaksananya program pencegahan IMS?}

"Agar semua kariawan disini bebas dari penyakit menular itu, tentunya kami mengikuti program dari KPA dan pemerintah yaitu setiap bulan dan

3 bulan sekali kami di periksa, semuanya diperiksa. Diberikan kartu periksa ke masing- masing kariawan kami” (KW1)

"Ada penyuluhan tentang HIV, IMS kemudian kami periksa kembali, ada kartu periksa kami dikasih"

"ya begitu tadi kami diminta tetap melapor kalau ada kariawan, kami tidak mau kena pelanggan disini sakit, jadi kami menyuruh semuanya ikut penyuluhan dan pemeriksaan kesehatan karena sudah diberikan kartu kesehatan juga, jadi setiap petugas datang itu diisi lagi, kalau tidak ada kan ketauan dia baru" (KW3)

\section{Strategi pencegahan}

IMS

di

Kabupaten Lombok Barat laksanakan dengan mempertimbangkan keadaan soaial maupun budaya yang ada di Lombok Barat. Melibatkan semua unsur sesuai dengan Peraturan daerah
Kabupaten Lombok Barat Nomor 3 tahun 2016 dan pasal 41 ayat 3 peraturan Bupati Lombok Barat Nomor 47 tahun 2014 tentang pencegahan dan penanggulangan HIV/AIDS, diinstruksikan kepada:
a. Kepala Dinas Kesehatan Lombok Barat
b. Kepala Dinas Sosial Kabupaten Lombok Barat
c. Kepala Dinas Kependudukan Dan Pencatatan Sipil Kesehatan Lombok Barat
d. Kepala Pengendalian Penduduk Keluarga Berencana Pemberdayaan Perempuan Dan Perlindungan Anak Kesehatan Lombok Barat
e. Kepala Dinas Pariwisata Kabupaten Lombok Barat
f. Kepala Dinas Penanaman Modal Dan Perizinan Terpadu Satu Pintu Kesehatan Lombok Barat
g. Kepala Dinas Tenaga Kerja Kesehatan Lombok Barat
h. Sekertaris Komisi Penanggulangan AIDS Kesehatan Lombok Barat
i. Kepala Satuan Polisi Pamong Praja Kesehatan Lombok Barat
j. Camat Se-Kesehatan Lombok Barat
k. Kepala Desa Se-Kesehatan Lombok Barat

Kotak 4

\section{Strategi apa yang dilakukan untuk meningkatkan terlaksananya program pencegahan IMS?}

"Kami bekerjasama dengan semua pihak, seperti perekrutan tenaga kerja di cafe atau SPA, mereka harus melampirkan rekam medis nya, kemudian pasangan yang mau menikah, harus di lakukan tes HIV. bersama PKBI kami mengadakan mobile VCT, kerjasama dengan puskesmas gunung sari juga. Karena untuk SDM di KPA memang terbatas dik, jadi kami bekerjasama dengan yang lain termasuk semua faskes di Lombok Barat” (TK)

Sarana dan prasarana yang tepat dan sesuai dengan standar Departemen kesehatan merupkan salah satu bentuk upaya dalam pencegahan HIV/AIDS. Sarana/prasarana tersebut adalah semua barang dan alat yang diperlukan untuk kegiatan program yang harus didistribusi tepat waktu. Pengadaan maupun pendistribusian diatur melalui mekanisme manajemen logistik yang dibuat oleh institusi pengadaan. Sampai saat ini bantuan berasal dari Global Fund. Pada tahun 2015 Global Fund sudah tidak lagi memberikan bantuan kepada Kabupaten Lombok Barat khususnya dan Indonesia pada umumnya karena Indonesia sudah dianggap mampu untuk malakukan upaya penanggulangan HIV/AIDS. Pemerintah daerah khususnya Kabupaten Lombok Barat diharapkan menjadikan isu HIV/AIDS ini menjadi 
prioritas dalam agenda pembangunan daerah dan di masukkan ke anggaran daerah.

2. Monitoring dan Evaluasi

Pembinaan kerjasama antar instansi dilaksanakan denganmeningkatkan koordinasi berbagai pihak dalam upaya penanggulangan HIV/AIDS yang mencakup aspek perencanaan, pembiayaan, penyelenggaraan dan monitoring evaluasi, maka dilakukan intervensi struktural dan penguatan Komisi Penanggulangan AIDS (KPA) Kabupaten Lombok Barat.

Penyelarasan dan pengintegrasian upaya penanggulangan HIV/AIDS dilaksanakan oleh lembaga pemerintah, LSM, masyarakat maupun dunia usaha sehingga program yang dilakukan menjadi menjadi efektif dan efisien. Advokasi Koordinasi dalam perencanaan, pelaksanaan dan evaluasi dilaksanakan sebagai bentuk wujud perhatian pemerintah dalam upaya penanggulangan HIV/AIDS. Sebagai dasar untuk melakukan interfensi dalam upaya pembangunan daerah di Kabupaten Lombok Barat pemerintah daerah sebagai top leader selalu membahas tentang isu-isu HIV/AIDS di dalam setiap rapat. Penguatan kepemimpinan dan komitmen pemerintah daerah telah dilaksanakan melalui Rapat Koordinasi bersama dinas/instansi terkait dengan peran aktif pimpinan daerah, pimpinan dinas/instansi, para Muspida dan legislatif dalam berbagai kegiatan yang berhubungan dengan upaya penanggulangan HIV/AIDS.

\section{Kotak 9 \\ Bagaimana proses monitoring dan evaluasi pelaksanaan kegiatan pencegahan IMS? \\ "dari kartu kontrol tadi dik, untuk memonitor kesehatan kariawan kami khususnya mengenai pengakit infeksi seksual itu" (KW1) \\ "selama kariawan bekerja berarti dari kartu kesehatan itu, cuman mereka ada yang kontrak 1 tahun dan lainnya, dan wajib itu" (KW2) "selain pemeriksaan kesehatan itu, kami juga ada program perawatan disini dik. Kalau dari Puskesmas tetap di kontrol di evaluasi setiap 1 bulan dan 3 bulan, kami juga memberikan perawatan di Spa ini” (KW3)}

Sesuai dengan instruksi Bupati Lombok Barat 2017 tentang pelaksanaan pemberian kartu kunjungan kesehatan. Kartu kunjungan kesehatan diberikan kepada para calon pekerja dan tempat-tempat hiburan, panti pijat, Spa, hotel-hotel, karaoke dan sejenisnya sebagai tindak lanjut dari hasil pemeriksaan kesehatannya di Puskesmas atau tempat pelayanan kesehatan lainnya sebagaimana tercantum Hasil Pemeriksaan (Perda Lombok Barat, 2017).

\section{Kotak 10 \\ Bagaimana proses monitoring dan evaluasi pelaksanaan kegiatan pencegahan IMS?}

"kami dari KPA sudah diberikan amanat oleh bupati untuk menjalankan upaya penanggulangan HIV termasuk disana adalah IMS, jadi kami laksanakan sesuai dengan Perda Lombok Barat No.3 tahun 2016 (sambil menunjukkan Perda yang dimaksud) ini baru Lombok Barat yang mempunyai peraturan. Jadi selama mereka bekerja dan tinggal di sini mereka harus mendapatkan layanan IMS ini. Namun hambatan kami saat sudah ada yang positif IMS, bahkan HIV adalah mereka tidak tinggal dan bekerja disini lagi, dengan alasan sudah selesai kontraknya. Sehingga pengobatan yang kami lakukan terputus karena mereka tidakmelaporkan diri pada saat selesai bekerja disini” (TK)

Upaya penanggulangan HIV/AIDS termasuk juga IMS tertuang dalam Peraturan daerah Kabupaten Lombok Barat Nomor 3 tahun 2016 dan pasal 41 ayat 3 peraturan Bupati Lombok Barat Nomor 47 tahun 2014 tentang pencegahan dan penanggulangan HIV/AIDS, perlu komitmen yang kuat dari SKPD terkait para pengusaha hiburan dalam pelaksanaan pemberian kartu kunjungan kesehatan kepada kariawan/karyawati yang bekerja di tempat hiburan.

\section{SIMPULAN DAN SARAN}

Hasil penelitian menunjukkan Pemilik Tempat Hiburan melakukan pencehan IMS melalui keikutsertaan pada program KPA dan karena adangan dukungan Pemda dalam program penanggulangan HIV/AIDS melalui diterbitkannya Perda tentang pelaksanaan pemberian kartu kunjungan kesehatan. KPA sebagai pemegang kendali dalam pelaksanaan program dengan bekerjasama lintas sektor.

Disarankan perlu partisipasi aktif dari stakeholders dalam kebijakan untuk meningkatkan perhatian terhadap pekerja di tempat hiburan yang terinfeksi IMS dan menjadikan isu HIV/AIDS sebagai kasus yang harus segera ditangani dan menjadi salah satu target pembangunan daerah sesuai dengan target SDG's.

\section{UCAPAN TERIMA KASIH}

Tim penulis mengucapkan terima kasih kepada Komisi Penanggulangan AIDS atas informasi tentang upaya penanggulangan HIV/AIDS dan akses untuk bertemu dengan sample penelitian di Kawasan Wisata Senggigi Lombok Barat. 


\section{DAFTAR RUJUKAN}

[1] Ardhiyanti. Konsep Dasar HIV/AIDS. Di Bahan Ajar AIDS Pada Asuhan Kebidanan. Edisi Pertama Penerbit : Publisher Yogyakarta, 2015.

[2] Azwar, A. Pengantar Administrasi Kesehatan, Edisi Ketiga, Binarupa Aksara. Jakarta, 2010.

[3] Bungin B. 2008. Penelitian Kualitatif, Komunikasi, Ekonomi, Kebijakan Publik, dan Ilmu Sosial lainnya. Kencana Predana Media Gru: Jakarta.

[4] Departemen Kesehatan RI. Lampiran KepMenKes RI no.567/Menkes/SK/VIII/2006 tentang pedoman pelaksanaan pengurangan dampak buruk narkotika, psikotropika dan zat adiktif. Jakarta, 2006.

[5] Dinas Kesehatan Provinsi NTB. Laporan Sero Survey Dinas Kesehatan Provinsi Nusa Tenggara Barat. Mataram, 2012.

[6] Dinkes NTB. Profil Kesehatan Nusa Tenggara Barat, Dinas Kesehatan Nusa Tenggara Barat, 2017.

[7] Dinkes Kota Mataram. Profil Kesehatan Kota Mataram, Dinas Kesehatan Kota Mataram, 2015.

[8] Kementerian Kesehatan RI. Pedoman Nasional Manajemen Program HIV dan AIDS. Jakarta, 2010.

[9] Kementerian Kesehatan RI. Rencana Strategi Pengendalian HIV/AIDS di Indonesia 2002- 2007. Jakarta, 2007.

[10] Kemenkes RI, (2018). Profil Kesehatan Indonesia, Kementrian Kesehatan RI

[11] Komisi Penanggulangan AIDS Nasional. Pedoman Nasional Monitoring, Evaluasi \& Pelaporan HIV dan AIDS. Komisi Penanggulangan AIDS Nasional. Jakarta, 2006.

[12] Komisi Penanggulangan AIDS Nasional. Rencana Aksi Penanggulangan Nasional 2003-2010. Jakarta, 2007

[13] Komisi Penanggulangan AIDS Nasional. Strategi Nasional Penanggulangan HIV dan AIDS Tahun 2007-2010. Komisi Penanggulangan AIDS Nasional. Jakarta, 2007.

[14] KPAN. Buku Pedoman Pelaksanaan Program Akselerasi Penanggulangan HIV/AIDS di 100

[15] Kabupaten/Kota. Sekertariat KPAN. Jakarta, 2006.

[16] KPAN. Mengenal dan Menanggulangai HIV/AIDS. Jakarta, 2006.

[17] Manuaba. Mitos-mitos seputar PMS, tersedia di http://www.bkkbn.go.id.hqweb/ceria/pengelola ceria/pp3pms.html diakses tanggal o3 Januari 2012.

[18] Miles, MB. Analisis Data Kualitatif. UI Press. Jakarta, 2007.

[19] Nasroudin. HIV \& AIDS, Pendekatan Biologi Molekuler, klinis dan social, Airlangga University Press. Surabaya, 2007.

[20] Peraturan Menteri Kesehatan RI nomor 21 tahun 2013 tentang penanggulangan HIV dan AIDS, 2013.

[21] PP\&PL D. Laporan Perkembangan HIV/AIDS Maret 2017. 2017; Available from:http://www.infopenyakit.org/def_menu.as p?menuId=14\&menuType $=1$ diakses tanggal 6 juli 2017 .

[22] Sugiono. Penelitian Kuantitatif dan Kualitatif R \& D. Bandung: AlfaBeta, 2008.

[23] The Joint United Nation Programme on HIV/AIDS (UNAIDS). Fact Sheet. London: Juli 2017 